\title{
Introduction: Maxine Greene on Democ- RACY AND THE SOCIAL IMAGINATION
}

\section{Kathleen Knight Abowitz}

In assembling scholars for the John Dewey Symposium for the 2015 Annual Meeting in Chicago, I sought thinkers who would critically engage Maxine Greene's philosophy of democratic education. The recent death of Greene (1917-2014), longtime member of the Society, friend and teacher of many members, and John Dewey Lecturer in 1988, had left a powerful absence among educational philosophers, and many had honored her legacy with loving tributes. The Symposium's aim was to bring together scholars in critical engagement with her work.

Greene had interpreted, critiqued, and in some ways enlarged Deweyan philosophy for much of her career. Key to her democratic educational thought was the concept of the social imagination:

We also have our social imagination: the capacity to invent visions of what should be and what might be in our deficient society, on the streets where we live, in our schools. As I write of social imagination, I am reminded of Jean-Paul Sartre's declaration that "it is on the day that we can conceive of a different state of affairs that a new light falls on our troubles and our suffering and that we decide that these are unbearable."

Three philosophers of education sought to explore the theme of social imagination in Greene's work. James Giarelli, Wendy Kohli, and James Stillwaggon contributed essays to the Symposium, which are published here. Maxine Greene herself is also published at the end of this set of papers. Giarelli, Kohli, and Stillwaggon all enjoyed rich relationships with Greene as her student, colleague, or friend, and usually in some combination of all three roles. Each of their essays here are cast within those relational webs. Together they weave a tribute that critically mines and extends Greene's insights on the social imagination and the possibilities for democratic education.

Giarelli's paper, "Maxine Greene on Progressive Education: Toward a Public Philosophy of Education," reveals a treasure-one found in the cleaning out of old files. Giarelli took the occasion of the Symposium to reveal a never-published manuscript written by Greene in 1984. That manuscript was written for a book project that never reached fruition. The book was to examine the contributions of 
The Social Frontier, a progressive education journal that was published from 1934 until 1939 (and as Frontiers of Democracy from 1939 to 1943). ${ }^{2}$ Greene sent Giarelli the manuscript, "Liberalism and Beyond: Toward a Public Philosophy of Education," in 1984, and he rediscovered it quite recently while cleaning out his files in preparation for retirement. We are honored to publish this "lost" manuscript of Greene's in this issue of Education and Culture.

Giarelli's essay revisits the connections between Greene and Dewey on democracy, particularly examining how their work both intersected with and diverged around democratic education themes. His essay examines Greene's relationship with liberalism and progressivism by revisiting his correspondences with Greene as well as themes in her 1984 manuscript. Greene's own essay narrates trends in educational philosophy and liberalism in her readings of issues of Social Frontier, providing a rich story of educational philosophy in North America and its perennial debates. Also revealed in Greene's essay is her lifelong relationship with progressivism and progressive education. She was an insider-outsider: Greene navigated the male-dominated worlds of philosophy and progressive education and embraced significant strands of progressive thought, but she also brought significant critical interpretations to the discourse through her existential, phenomenological, and aesthetic treatments of democratic ideas. This liminal engagement with democratic progressivism yielded a rich "critical and complicated arc of thought," as Giarelli notes of Greene's work. Giarelli writes that for Greene, "a public philosophy of education must take biographies, background awareness, interpreted experience, and point of view into account," which underscores the historical and the personal in the appearance of both Giarelli's and Greene's essays here.

Wendy Kohli, in "The Dialectical Imagination of Maxine Greene: Social Imagination as Critical Pedagogy," reminds us of Greene's existentialism as a tool for situating consciousness in the context of our own lived experiences in the world. Greene was always, throughout her life, on a search for freedom; she was becoming, always. Kohli's essay reminds us of this strong theme in one of her early books, Teacher as Stranger, one of the great existentialist treatments of the classroom teachers' work and predicaments. ${ }^{3}$ Kohli works across many of Greene's books and essays to discuss the social imagination and its potential and actual impact on the education of teachers through Greene's pragmatic activism. She concludes by showing us the influence of Greene's work on her own critical pedagogy in a course called "The Educational Imagination" that she taught regularly at her home institution.

The social imagination is thus often evoked in Greene's work to suggest that we can re-create the world by both becoming uncomfortably disturbed by the status quo, and by being stimulated and pushed to envision a better society. But James Stillwaggon more deeply probes the uses of imagination in "Two Functions of the Imagination in Greene's Aesthetic Educational Theory." In an essay that draws on Platonic and Lancanian psychoanalytic insights, Stillwaggon argues 
for the paradoxical power of the imagination as a disruptive, undermining force to present conceptions of self and reality, as well as an integrative and coordinating aspect of human experience. The power of the image is the example explored in this essay, as Stillwaggon describes "how the image serves as both the subject's entry point into the world of human community and as the means by which one's relationship to discursive norms might be overcome, or at least upset." Through examining images as powerful as one's own reflection seen for the first time as a baby, to images of civil rights workers and police brutality in contemporary US life, he shows how images both disrupt and potentially integrate into new narratives of social reality as we imagine the world otherwise. In doing so, Stillwaggon brings Greene's work into compelling conversation with various worlds of traditions and philosophical thinkers, using a style that is in some senses reminiscent of Greene's.

The John Dewey Society is proud to sponsor the publication of these essays in Education and Culture as a unique, scholarly, and personal tribute to the democratic legacy of Maxine Greene.

\section{Notes}

1. Maxine Greene, Releasing the Imagination: Essays on Arts, Education and Social Change (New York: Teachers College Press, 2000), 4.

2. See Social Frontier/Frontiers of Democracy, online archives-available here: https:// www.tcrecord.org/frontiers/home.asp.

3. Maxine Greene, Teacher as Stranger: Educational Philosophy for the Modern Age (New York: Wadsworth, 1973).

Kathleen Knight Abowitz is Chair of the Department of Educational Leadership at Miami University. Email: knight2@miamioh.edu 
